\title{
Strategi Guru PAI dalam Meningkatkan Kecerdasan Spiritual Peserta Didik
}

Oleh: Hosaini

$*$

Email: hosaini2612@gmail.com

Universitas Bondowoso, Indonesia

\begin{abstract}
Abstrak
Pada hakikatnya pendidikan merupakan salah satu komponen yang harus diutamakan oleh manusia di dalam menjalani kehidupan menuju hidup yang lebih baik. Penelitian ini terfokus pada strategi guru PAI dalam meningkatkan kecerdasan spiritual peserta didik di SMA Negeri 2 Situbondo, dengan menggunakan pendekatan kualitatif. Hasil dari pembahasan ini peneliti akan menjelaskan tentang data-data yang diperoleh melalui metode observasi, wawancara dan dokumentasi yang didapat di lembaga. Kesimpulan Bahwa penerapan strategi guru PAI dalam meningkatkan kecerdasan spiritual peserta didik di SMA Negeri 2 Situbondo adalah memberi tambahan kegiatan keagamaan, membiasakan peserta didik mengikuti kegiatan-kegiatan keagamaan, memulai dan mengakhiri pelajaran dengan do'a, menampilkan video-video yang mengandung hikmah, melihat individu dan kemampuan peserta didik, memberi nasehat dan tanya jawab, berdzikir dan mendo'akan peserta didik.
\end{abstract}

Keywords : Strategi, Guru PAI, SQ Peserta didik. 


\section{Pendahuluan}

Pada hakikatnya pendidikan merupakan salah satu komponen yang harus diutamakan oleh manusia di dalam menjalani kehidupan menuju hidup yang lebih baik. Statemen ini dapat dijewantahkan karena hanya melalui proses pendidikan manusia akan tumbuh berkembang baik jasmani maupun rohani sehingga dapat mengantarkan manusia itu sendiri ke taraf insani. hal ini sejalan dengan apa yang diungkapkan oleh Driyarkara bahwa, inti penddikan adalah pemanusiaan manusia muda. Pada dasarnya pendidikan adalah pengembangan manusia muda ke taraf insani. ${ }^{1}$

Pendidikan adalah suatu aktivitas untuk mengembangkan seluruh aspek kepribadian manusia yang berjalan seumur hidup. Dengan kata lain, pendidikan tidak hanya berlangsung di dalam kelas, tetapi berlangsung pula di luar kelas. Pendidikan bukan hanya bersifat formal, tetapi juga non formal. Secara substansial, pendidikan tidak sebatas pengembangan intelektualitas manusia, artinya tidak hanya meningkatkan kecerdasan, melainkan mengembangkan seluruh aspek kepribadian manusia. Pendidikan merupakan sarana utama untuk mengembangkan kepribadian setiap manusia. $^{2}$

Di dalam UU No. 20/2003 tentang Sistem Pendidikan Nasional, tercantum pengertian pendidikan: "Pendidikan adalah usaha sadar dan terencana untuk mewujudkan suasana belajar dan proses pembelajaran agar peserta didik secara aktif

\footnotetext{
${ }^{1}$ Wiji Suwarno, 2006. Dasar-Dasar

Ilmu Pendidikan. yogyakarta: Penerbit Arruzz Media Cet Ke 1.hal 21

${ }^{2}$ Hasan Basri, 2009. Filsafat pendidikan Islam. Bandung: Pustaka Setia. Cet. Ke-1. hal. 53
}

mengembangkan potensi dirinya sehingga memiliki kekuatan spiritual keagamaan, pengendalian diri, kepribadian, kecerdasan, akhlak mulia, serta keterampilan yang diperlukan oleh dirinya, masyarakat, bangsa, dan negara". 3

Dari pengertian di atas, secara umum, pendidikan adalah proses pembinaan manusia secara jasmaniah dan rohaniah. Artinya, setiap upaya dan usaha untuk meningkatkan kecerdasan anak didik berkaitan dengan intelegensi, emosi, dan kecerdasan spiritualnya. ${ }^{4}$

Membina dan membentuk manusia secara jasmaniah dan rohaniah merupakan salah satu unsur dan tujuan utama pendidikan. Artinya tidak hanya membina kecerdasan intelektual dan emosionalnya saja tapi yang paling utama adalah kecerdasan spiritualnya karena kecerdasan spiritual merupakan landasan yang diperlukan untuk memfungsikan kecerdasan intelektual dan kecerdasan emosional secara efektif. Bahkan kecerdasan spiritual (SQ) merupakan kecerdasan tertinggi. ${ }^{5}$

Di dalam UU No. 20/2003 tentang Sistem Pendidikan Nasional pasal 77 juga tercantum bahwa, pendidikan menengah bertujuan membentuk peserta didik menjadi insan yang beriman dan bertakwa kepada Tuhan Yang maha Esa, beraklak mulia, dan berkepribadian luhur. $^{6}$ tujuan

${ }^{3}$ Peraturan Perundang-undangan RI Nomor 20 Tahun 2003 Tentang, Sisdiknas \& Peraturan Pemerintah RI Tahun 2010 Tentang Penyelenggaraan Pendidikan serta Wajib Belajar. Bandung: Citara Umbara. Cet. Ke-4. hal. 2-3

Islam. hal. 54

${ }^{4}$ Hasan Basri, Filsafat pendidikan

${ }^{5}$ Baharuddin dan Esa Nur Wahyuni, 2008. Teori Belajar dan Pembelajaran. Yogyakarta: Ar-Ruzz Media Cet. Ke 2 .hal. 161

${ }^{6}$ Peraturan Perundang-undangan RI Nomor 20 Tahun 2003 Tentang, Sisdiknas \& 
pendidikan ini sesuai dengan firman Allah di dalam Al-qur'an

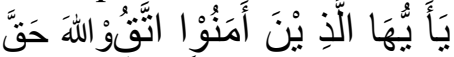

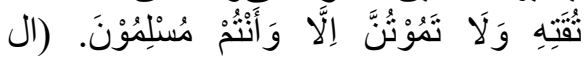

$$
\begin{aligned}
& \text { عمر ان، 3: 102 }
\end{aligned}
$$

Artinya: "hai-hai orang-orang yang beriman bertakwalah kepada Allah sebenar Benar takwa kepadanya; dan janganlah sekali-kali kamu mati melainkan Dalam keadaan beragama Islam. (Ali 'Imran (3) : 102).

Namun pada kenyataannya akhir-akhir ini seolah-olah pendidikan tidak memberikan bukti yang riil di dalam meningkatkan kecerdasan spiritual (SQ) yang merupakan salah satu unsur dan tujuan pendidikan. Pernyataan ini termanifestasikan lantaran masih adanya peserta didik yang tidak memahami, menghayati, mengaplikasikan, dan meinginternalisasikan nilai-nilai pendidikan. Dan inilah yang menjadi problem sekaligus tantangan di dalam dunia pendidikan yang harus segera diatasi.

Oleh karena itu maka dalam pelaksanaannya pendidikan itu perlu adanya proses belajar mengajar. Karena memang dalam keseluruhan proses pendidikan, kegiatan belajar dan mengajar merupakan kegiatan yang paling pokok. Hal ini berarti bahwa berhasil - tidaknya pencapaian tujuan pendidikan bergantung kepada bagaimana proses belajar mengajar dirancang dan dijalankan secara profesional.

Setiap kegiatan belajar mengajar selalu melibatkan dua pelaku aktif, yaitu guru dan siswa. Guru sebagai pengajar merupakan pencipta kondisi belajar siswa yang didesain secara sengaja, sistematis dan

Peraturan Pemerintah RI Tahun 2010 Tentang Penyelenggaraan Pendidikan serta Wajib Belajar. Bandung: Citara Umbara. Cet. Ke-4. hal. 271 berkesinambungan sedangkan anak didik sebagai subyek pembelajaran merupakan pihak yang menikmati kondisi belajar yang diciptakan guru. ${ }^{7}$

Untuk mewujudkan tujuan pencapaian pendidikan yang diproses melalui kegiatan belajar mengajar bukanlah perkara yang mudah karena harus melalui beberapa tahapantahapan dan itupun belum tentu akan mendapatkan hasil yang maksimal. hal semacam inilah yang menjadi tantangan bagi para pendidik sebagai pelaksana pendidikan. Dengan demikian maka, seorang pendidik di tuntut melakukan usaha dan upaya untuk menciptakan suasana belajar mengajar yang konduktif dan menyenangkan.

Menciptakan kegiatan belajar mengajar yang konduktif dan menyenangkan tentu diperlukan adanya strategi, karena strategi meupakan cara yang sangat efektif di dalam mencapai tujuan yang diinginkan oleh instansi pada khususnya dan tujuan belajar mengajar, serta tujuan pendidikan pada umumnya yaitu membina dan membentuk manusia yang cerdas secara intelektual, emosional dan yang paling utama adalah kecerdasan spiritualnya (SQ). Statemen ini selaras dengan apa yang diungkapkan oleh Joni bahwa, strategi adalah suatu prosedur yang digunakan untuk memberikan suasana yang konduktif kepada siswa dalam rangka mencapai tujuan pembelajaran. ${ }^{8}$

Oleh sebab itu untuk mengoptimalkan dan memaksimalkan

${ }^{7}$ Pupuh Fathurrohman dan M. Sobry Sutikno, 2007. Strategi Belajar Mengajar Melalui Penanaman Konsep Umum \& Konsep Islami. Bandung: PT Refika Aditama, Cet. Ke- 1 , hal 8

${ }^{8}$ Hamdani, 2010. Srtategi Belajar

Mengajar. Bandung : Pustaka Setia, Cet. Ke 10, h.18 
tujuan pendidikan dan proses belajar mengajar maka pengelola pendidikan ataupun guru sebagai pelaksana pendidikan diupayakan paham dan mampu di dalam menerapkan strategi dengan baik dan akurat.

Mengingat pentingnya tataran konteks penelitian di atas maka, penulis merasa tertarik untuk mengangkat judul "Strategi Guru PAI dalam Meningkatkan Kecerdasan Spiritual Peserta Didik di SMA Negeri 2 Situbondo Tahun Pelajaran 2017/2018." Tujuan Ingin mendeskripsikan penerapan strategi guru PAI dalam meningkatkan kecerdasan spiritual peserta didik Ingin, dan mendeskripsikan faktorfaktor yang mendukung dan menghambat penerapan strategi guru PAI dalam meningkatkan kecerdasan spiritual peserta didik serta Ingin mengidentifikasi solusi mengatasi hambatan penerapan strategi guru PAI dalam meningkatkan kecerdasan spiritual peserta didik di SMA Negeri 2 Situbondo Tahun Pelajaran 2017/2018?

\section{Kajian Konseptual}

Dalam kajian terdahulu peneliti dapat menguraikan dua hal diantaranya adalah:

Strategi guru dalam mengembangkan kreativitas peserta didik di MTs Miftahul Ulum Lenteng Tahun pelajaran 2008/2009, penelitian ini dilakukan oleh Mohammad, ia menarik sebuah kesimpulan dari hasil penelitiannya bahwa strategi guru dalam mengembangkan kretivitas peserta didik di MTs Miftahul Ulum Lenteng ialah dengan menggunakan pendekatan Contextual Teaching and Learning (CTL), pendekatan kelompok, pendekatan individual, menerapkan metode diskusi, metode dialog dan metode ceramah. Adapun faktor-faktor penghambat adalah meliputi: lingkungan masyarakat, lingkungan keluarga. Sedangkan faktor-faktor pendukung adalah meliputi: motivasi, minat, guru dan penilaian.

Bedanya penelitian ini adalah peneliti lebih fokus kepada strategi guru PAI dalam meningkatkan kecerdasan spiritual peserta didik.

\section{Metode}

Penelitian ini terfokus pada strategi guru PAI dalam meningkatkan kecerdasan spiritual peserta didik di SMA Negeri 2 Situbondo, dengan menggunakan pendekatan kualitatif. Bogdan dan Taylor mendefinisikan pendekatan/metode penelitian kualitatif sebagai prosedur penelitian yang menghasilkan data deskriptif berupa kata-kata tertulis atau lisan dari orangorang dan perilaku yang dapat diamati. Menurut mereka, pendekatan ini diarahkan pada latar dan individu tersebut secara holistik. ${ }^{9}$

1. Jenis Penelitian

Dalam penelitian ini peneliti menggunakan jenis penelitian kualitataif deskriptif. Menurut Lexy J. Moleong, data yang dikumpulkan dalam deskriptif ini adalah berupa kata-kata, gambar, dan bukan angkaangka. Hal itu disebabkan oleh adanya penerapan metode / pendekatan kualitatif. Selain itu, semua yang dikumpulkan berkemungkinan menjadi kunci terhadap apa yang sudah diteliti. ${ }^{10}$

\section{A. Kehadiran Peneliti}

Peneliti hadir di lembaga SMA Negeri 2 Situbondo, pertama kali peneliti akan mendatangi kepala sekolah (Dra. Endang Wiji

${ }^{9}$ Lexy J. Moleong, 2012. Metodologi penelitian kualitatif. Bandung: PT Remaja Rosdakarya. Cet. Ke 30. hal.4

${ }^{10}$ Ibid., h. 11 
Lestari, M.M) untuk memberitahukan dan meminta izin penelitian, untuk meneliti tentang "strategi guru PAI dalam meningkatkan kecerdasan spiritual peserta didik di SMA Negeri 2 Situbondo tahun pelajaran 2017/2018”. Setelah itu peneliti akan mendatangi bagian tata usaha dan kaur kurikulum untuk memberikan surat tugas penelitian agar dijadikan arsip di ruang tata usaha. Selanjutnya peneliti melaksanakan penelitian sebagaimana mestinya di SMA Negeri 2 Situbondo.

\section{B. Lokasi Penelitian}

SMA Negeri 2 Situbondo merupakan salah satu lembaga formal yang berada di kabupaten Situbondo. sedangkan lokasi SMA Negeri 2 Situbondo berada di tempat yang sangat strategis terletak ditengah-tengah kota Situbondo yaitu J1. PB. Sudirman 5a Situbondo 68312 yang berada disebelah timur SMA Negeri 2 Situbondo dan sebelah barat Universitas Abdurrahman Shaleh Situbondo. Sarana transportasi mudah dijangkau, SMA Negeri 2 Situbondo juga dekat dengan POLRES Situbondo sehingga mudah berkomunikasi dengan keamanan.

\section{Sumber Data}

Menurut lofland sumber data utama dalam penelitian kualitatif adalah kata-kata, dan tindakan, selebihnya adalah data tambahan seperti dokumen dan lain-lain. Baerkaitan dengan hal itu pada bagian ini jenis datanya dibagi ke dalam kata-kata dan tindakan, sumber data tertulis, foto, dan statistik. ${ }^{11}$

1. Kata-kata dan tindakan

Kata-kata dan tindakan orang-orang yang diamati atau diwawancarai merupakan sumber data utama. Sumber data utama dicatat melalui catatan tertulis atau melalui perekaman video / audio tapes, pengambillan foto, atau film.

Pencatatan sumber data utama melalui wawancara atau pengmatan berperanserta merupakan hasil usaha gabungan dari kegiatan melihat, mendengar, dan bertanya. Manakah di antara ketiga kegiatan yang dominan, jelas akan bervariasi dari satu waktu ke waktu lain dan dari satu situasi ke situasi lainnya. Misalnya, jika peneliti merupakan pengmat tak diketahui pada tempat-tempat umum, jelas bahwa melihat dan mendengar merupakan alat utama, sedangkan bertanya akan terbatas sekali. Sewaktu peneliti memanfaatkan wawancara mendalam, jelas bahwa bertanya dan mendengar akan merupakan kegiatan pokok.

\section{Pembahasan}

Temuan Penelitian

Temuan penelitian ini membahas strategi guru PAI dalam meningkatkan kecerdasan spiritual peserta didik di SMA Negeri 2 Situbondo, yang didapat melalui hasil observasi, interview, dan dokumentasi, dengan ini maka,

${ }^{11}$ Lexy J. Moleong, Metodologi penelitian kualitatif. hal. 157-163 
peneliti menemukan beberapa hal, sebagai berikut:

a. Penerapan Strategi guru PAI dalam meningkatkan kecerdasan spiritual Peserta didik di SMA Negeri 2 Situbondo

Strategi guru PAI dalam meningkatkan kecerdasan spiritual peserta didik di SMA Negeri 2 Situbondo. Dalam meningkatkan kecerdasan spiritual peserta didik bukanlah merupakan perkara yang mudah. Oleh karena itu maka dalam hal ini diperlukan adanya suatu strategi yang dapat diterima oleh peserta didik.

Strategi merupakan rencana cermat, siasat, atau cara untuk mencapai tujuan tertentu (yang diinginkan). Maka dalam hal ini SMA Negeri 2 Situbondo yang merupakan salah satu lembaga yang telah mempersiapkan guruguru berkualitas, mengedepankan sopan santun, iman dan taqwa yang akan mencetak kader-kader bangsa yang cerdas secara jasnaniah dan rohaniah, artinya tidak hanya mencetak kader-kader bangsa yang cerdas intelektualnya, emosionalnya, tapi juga mencetak kader-kader yang cerdas spiritualnya. Untuk itu maka penulis merasa sangat penting untuk mengetahui bagaimana "Strategi Guru PAI dalam meningkatkan Kecerdasan Spiritual Peserta Didik di SMA Negeri 2 Situbondo. Berikut hasil wawancara peneliti dengan bapak Moh. Nur Budi, S.Ag:

"strategi yang saya terapkan adalah memberi tambahan kegiatan keagamaan, dan tambahan kegiatan keagamaan ini juga merupakan cara yang diterapkan di SMA Negeri 2 Situbondo supaya kecerdasan spiritual anak-anak bisa berkembang sedikit demi sedikit tapi berarti. Sedangkan tambahan kegiatan yang saya maksud kuarng lebih ada empat belas, diantaranya: (1) do'a awal pelajaran, (2) do'a akhir pelajaran, (3) sholat jum'at, (4) amaliah jum'at, (5)KHARISMADA, istighotsah, (7) peringatan maulid Nabi Muhammad SAW, peringatan isro' mi'roj, (9) sholat tarowih, (10) tadarrus Qur'an romadhon, (11) pesantren romadhon, (12) pembagian buka puasa, (13) penerimaan dan pembagian zakat fithroh, (14) penyembelihan dan pembagian daging Qurban. Selain itu juga saya membiasakan anak-anak untuk mengikuti kegiatan-kegiatan yang tadi tujuannya untuk meningkatkan kecerdasan spiritual peserta didik." 12

Lebih lanjut lagi peneliti wawancara kepada Ibu Syu'layya Farida salah satu guru PAI di SMA Negeri 2 Situbondo, berikut hasil wawancara:

"Saya lebih fokus pada perkelasnya, mungkin kalau Pak Nur Budi kan kesluruhan, kalau saya strateginya, memulai dengan bacaan-bacaan do'a kemudian juga sering ditampilkan video-video tentang hikmah-hikmah yang terkandung seperti itu, jadi anakanak juga bisa memikirkan apa yang misalkan mereka kerjakan juga bagaimana hikmahnya atau bagaimana balasannya. Kemudian diakhir pembelajaran diingatkan untuk mengucap bacaan-bacaan do'a gunanya untuk meningkatkan kecerdasan spiritual mereka selain

${ }^{12}$ Moh. Nur Budi, Guru PAI SMA Negeri 2 Situbondo, Wawancara Pribadi, Situbondo, 26 April 2014 
itu saya juga melihat individu peserta didik Ketika siswa itu memang sudah mempunyai dasar dan punya kemauan untuk sholat, jadi saya menekankan agar dibiasakan sedangkan sebaliknya perlu penanaman dari awal penyadaran." 13

Lebih lanjut peneliti wawancara kepada Amaliyah Rahmah salah satu siswa kelas XI IPA 1

"Menurut saya strategi guru agama untuk meningkatkan kecerdasan spiritual peserta didik sangat bagus, memberikan semacam nasehatnasehat dan tanya jawab, biasanya juga ngasih kertas lembaran yang isinya materi, dan materinya itu dijelaskan dan harapan dari guru tersebut siswa bisa melaksanakan materi-materi tersebut."14

Kemudian peneliti melanjutkan wawancara kepada Bapak Mudhaffar, salah satu guru PAI di SMA Negeri 2 Situbondo, hasil wawancara sebagai berikut:

"Biasanya saya menggunakan pendekatan dzikir, di samping dzikir, juga setiap selesai sholat jama'ah saya selalu mendo'akan anak-anak, dan saya sampaikan kepada anak-anak bahwa saya tidak hanya mengajar kalian tapi juga mendo'akan."15

b. Faktor-faktor yang Mendukung dan Menghambat Penerapan Strategi Guru PAI dalam Meningkatkan

\footnotetext{
${ }^{13}$ Syu'layya Farida, Guru PAI/PBDKT SMA Negeri 2 Situbondo, Wawancara Pribadi, Situbondo, 26 April 2014

${ }^{14}$ Amaliyah Rahmah, Siswa Kelas XI IPA 1 SMA Negeri 2 Situbondo, Wawancara Pribadi, Situbondo, 30 April 2014

${ }^{15}$ Mudhaffar, Guru PAI SMA Negeri 2 Situbondo, Wawancara Pribadi, Situbondo, 21 Mei 2014
}

Kecerdasan Spiritual Peserta Didik Di SMA Negeri 2 Situbondo

Dalam penerapan suatu strategi sudah barang tentu terdapat faktor-faktor yang mendukung dan faktor yang menghambat.

Berdasarkan hasil wawancara kepada guru PAI dan siswa yang telah peneliti lakukan, terdapat beberapa faktor yang mendukung dan menghambat Strategi Guru PAI dalam meningkatkan Kecerdasan Spiritual Peserta didik di SMA Negeri 2 Situbondo adalah sebagai brikut:

1. Faktor yang mendukung

Berikut hasil wawancara peneliti dengan Ibu Syu'layya Farida tentang faktor yang mendukung penerapan strategi guru PAI dalam meningkatkan kecerdasan spiritual peserta didik di SMA Negeri 2 Situbondo:

"menurut saya faktor yang mendukung adalah adanya minat anak untuk belajar lebih lanjut pengetahuan tentang agama, dan kesadaran dari anak didik masing-masing untuk belajar sealin itu juga dukungan dari sebagian wali murid, dengan menanyakan anaknya bagaimana sholatnya bagaimana kegiatannya di sekolah dia rajin apa tidak."16

Selain itu peneliti juga wawancara kepada Amaliyah Rahmah, salah satu siswa kelas XI IPA 1 berikut hasil wawancara:

"menurut saya faktor yang mendukung adalah

\section{${ }^{16}$ Syu'layya Farida, Guru}

PAI/PBDKT SMA Negeri 2 Situbondo, Wawancara Pribadi, Situbondo, 26 April 2014 
keingintahuan siswa untuk belajar agama." 17

kemudian peneliti wawancara kepada Bapak Moh. Nur Budi, salah satu guru PAI di SMA Negeri 2 Situbondo, hasil wawancara sebagai berikut:

"Menurut saya faktor yang mendukung adalah kepala sekolah mengapresiasi dan mendukung terhadap langkah-langkah guru PAI dari kelas X, XI, XII untuk membentuk kecerdasan spiritual anak. kemudian dari rekan-rekan guru juga sangat mengapresiasi dan mendukung seperti kepala sekolah tadi. Dari murid-murid terutama di kelas unggulan itu berpartisipasi aktif dalam kegiatan-kegiatan keagamaan yang berujung terbentuknya kecerdasan spiritual itu yang empat belas kegiatan dalam satu tahun itu"18

Kemudian peneliti wawancara kepada Bapak $\mathrm{H}$. Mudhaffar, Guru PAI SMA Negeri 2 Situbondo.

"menurut saya faktor yang mendukung adalah kesadaran dari sebagian anak-anak untuk melaksanakan nilai-nilai pendidikan agama, ini saya lihat ketika jam istirahat sebagian anakanak menyempatkan diri untuk sholat dhoha."19

2.

Faktor yang menghambat

${ }^{17}$ Amaliyah Rahmah, Siswa Kelas XI IPA 1 SMA Negeri 2 Situbondo, Wawancara Pribadi, Situbondo, 30 April 2014

${ }^{18}$ Moh. Nur Budi, Guru PAI SMA

Negeri 2 Situbondo, Wawancara Pribadi, Situbondo, 7 Mei 2014

${ }^{19}$ Mudhaffar, Guru PAI SMA Negeri 2 Situbondo, Wawancara Pribadi, Situbondo, 21 Mei 2014
Dalam penerapan suatu strategi sudah barang tentu terdapat faktor-faktor yang menghambat, berikut hasil wawancara peneliti kepada Ibu Syu'layya Farida Guru PAI SMA Negeri Situbondo:

"Menurut saya ada sebagian orang tua siswa yang tidak mendukung ini kemarin saya temukan ketika anaknya tersebut berbuat kebaikan malah oleh orang tuanya diabaikan. Dan bahkan ketika dia mau melakukan sholat malah oleh orang tuanya digojlokin." 20

Selanjutnya peneliti wawancara kepada Amaliyah Rahmah salah satu siswa kelas XI IPA 1, hasil wawancara sebagai berikut:

"Menurut saya faktor penghambatnya adalah dari siswanya sendiri. Akan tetapi lebih banyak yang mendorong dari pada yang menghambat." 21

Kemudian peneliti melanjutkan wawancara kepada Bapak Moh. Nur Budi, Guru PAI SMA Negeri 2 Situbondo, berikut hasil wawancara:

"Menurut saya, faktor penghambatnya mungkin hanya membutuhkan waktu agar pemahaman kepada seluruh siswasiswi kelas X, XI, samapai kelas XII bahwa kegiatan-kegiatan keagamaan yang dirutinkan bertujuan untuk membentuk kecerdasan spiritual mereka, karena

${ }^{20}$ Syu'layya Farida, Guru PAI/PBDKT SMA Negeri 2 Situbondo, Wawancara Pribadi, Situbondo, 26 April 2014

${ }^{21}$ Amaliyah Rahmah, Siswa Kelas XI IPA 1 SMA Negeri 2 Situbondo, Wawancara Pribadi, Situbondo, 30 April 2014 
pengalaman guru agama, sebenarnya kebanyakan anak-anak itu punya semangat untuk aktif di dalam seluruh kegiatan keagamaan yang empat belas itu, cuma karena pengaruh teman, terkadang karena banyak jadwal-jadwal kegiatan yang berbenturan dengan kegiatankegiatan tersebut. Sehingga, mengakibatkan mereka tidak fokus mana yang lebih didahulukan." 22

Sealanjutnya peneliti wawancara kepada Bapak $\mathrm{H}$. Mudhaffar Guru PAI SMA Negeri 2 Situbondo, hasil wawancara sebagai berikut:

"Menurut saya faktor yang menghambat adalah kondisi pengaruh lingkungan dan pergaulan anak di rumah, sehingga sering kali saya menanyakan apakah di rumah kalian sholat, sebagian ada yang menjawab kadang-kadang.,"23

c. Solusi Mengatasi Hambatan Penerapan Strategi Guru PAI dalam Meningkatkan Kecerdasan Spiritual Peserta Didik di SMA Negeri 2 Situbondo:

Hasil wawancara peneflitiam kepada Ibu Syu'layya Farida, S.Pd.I sebagai berikut:

"Menurut saya, untuk mengatasi hambatan sebagian orang tua yang kurang mendukung adalah memberikan pengertian lebih lanjut keapada orang tua yaitu dengan harapan agar orang tua tersebut dapat bekerjasama dengan sekolah." 24

${ }^{22}$ Moh. Nur Budi, Guru PAI SMA Negeri 2 Situbondo, Wawancara Pribadi, Situbondo, 7 Mei 2014

${ }^{23}$ Mudhaffar, Guru PAI SMA Negeri 2 Situbondo, Wawancara Pribadi, Situbondo, 21 Mei 2014

${ }^{24}$ Syu'layya Farida, Guru PAI/PBDKT SMA Negeri 2 Situbondo,
Hasil wawancara peneliti kepada bapak Nur Budi guru PAI SMA Negeri 2 Situbondo:

"menurut saya solusinya adalah memberikan semacam motivasimotivasi sebelum pembelajaran dimulai, terus dalam kegiatan keagamaan berusaha menghadirkan, ambil contoh kegiatan maulid isro' mi'raj dan rangkaian-rangkaian istghotsah tiap bulan dan istigotsah penutup menghadirkan penceramahpenceramah yang memang berkualitas dari segi pemahaman berpikir dan pemahaman rohani." 25

Lebih lanjut peneliti wawancara kepada Bapak Mudhaffar guru PAI SMA Negeri 2 Situbondo, berikut hasil wawancara:

"Saya memberikan semcam lembar kontrol kepada anak-anak dalam satu bulan satu kali, dalam lembaran itu saya menanyakan tentang kegiatan anak-anak di rumah." 26

Kajian Pembahasan

pembahasan ini peneliti akan menjelaskan tentang data-data yang diperoleh melalui metode observasi, wawancara dan dokumentasi yang didapat di lembaga SMA Negeri 2 Situbondo. Oleh sebab itu, untuk mengvalidkan data-data lapangan tersebut di bawah ini peneliti akan memaparkan perpaduan sebagian teori-teori yang diyakini relevan dengan yang senyatanya

Wawancara Pribadi, Situbondo, 26 April 2014

${ }^{25}$ Moh. Nur Budi, Guru PAI SMA

Negeri 2 Situbondo, Wawancara Pribadi, Situbondo, 7 Mei 2014

${ }^{26}$ Mudhaffar, Guru PAI SMA Negeri 2 Situbondo, Wawancara Pribadi, Situbondo, 21 Mei 2014 

itu terlebih dahulu telah di dibangun pada bab II.

1. Penerapan Strategi Guru PAI dalam meningkatkan Keerdasan Spiritual Peserta Didik di SMA Negeri 2 Situbondo.

$$
\text { Strategi yang }
$$
diterapkan oleh guru PAI di SMA Negeri 2 Situbondo merupakan salah satu cara untuk mencapai tujuan kegiatan belajar mengajar baik formal, nonformal maupun informal. Hal ini selaras dengan pernyataan Hamdani bahwa, secara umum strategi dapat diartikan sebagai suatu upaya yang dilakukan oleh seseorang atau organisasi untuk sampai pada tujuan. Dalam kamus besar bahasa indonesia, strategi adalah rencana yang cermat mengenai kegiatan untuk mencapai sasaran khusus (yang diinginkan). Joni berpendapat bahwa yang dimaksud strategi adalah suatu prosedur yang digunakan untuk memberikan suasana yang konduktif kepada siswa dalam rangka mencapai tujuan pembelajaran. ${ }^{27}$

\begin{tabular}{l}
\multicolumn{2}{c}{ Berdasarkan hasil } \\
observasi, inteview, dan \\
dokumentasi tentang strategi \\
guru PAI dalam meningkatkan
\end{tabular}
kecerdasan spiritual peserta didik di SMA Negeri 2 Situbondo dapat dianalisis dan dideskripsikan sebabagai berikut: dilapangan sebagaimana teori-teori

Menurut Bapak Moh. Nur Budi, di SMA Negeri 2 Situbondo terdiri dari emapat belas cara dalam meningkatkan kecerdasan spiritual peserta didik. di antara emapat belas cara atau uapaya-upaya yang memang perlu dilaksanakan oleh seorang guru dalam meningkatkan kecerdasan spiritual peserta didik di SMA Negeri 2 Situbondo itu berupa kegiatan-kegiatan keagamaan. Hal ini sesuai dengan apa yang diungkapakan Hamdani bahwa, salah satu ciri-ciri strategi adalah pemusatan upaya, sebuah strategi yang efektif biasanya mengharuskan pemusatan kegiatan, upaya atau perhatian rentang sasaran yang sempit. ${ }^{28}$

Selain itu bapak Moh. Nur Budi menegaskan bahwa, untuk meningkatkan kecerdasan spiritual peserta didik di SMA Negeri 2 Situbondo diperlukan adanya pembiasaan kepada peserta didik untuk proaktif di dalam mengikuti kegiatan-kegiatan keagamaan. Dalam srategi ini peserta didik berposisi sebagai objek. Jika posisi siswa sebagai objek dalam penerapan suatu strategi berarti strategi yang diterapakan mengarah keapada pendekatan pembelajaran berorientasi pada guru (teacher centered approaches). Menurut Rusman pendekatan ini berorientasi pada guru yaitu pembelajaran yang menempatkan siswa

${ }^{27}$ Hamdani, 2010. Srtategi Belajar Mengajar. Bandung : Pustaka Setia, Cet. Ke 10, h. 18 $\begin{array}{ll}{ }^{28} \text { Hamdani, } & \text { Srtategi Belajar } \\ \text { Mengajar. h. } 18 & \end{array}$ 
sebagai objek dalam belajar mengajar dan kegiatan belajar bersifat klasik. Dalam pendekatan ini guru menempatkan diri sebagai orang yang serba tahu dan sebagai satu-satunya sumber belajar.

Pendekatan yang berpusat pada guru memiliki ciri bahwa manajemen dan pengelolaan pembelajaran ditentukan sepenuhnya oleh guru. Siswa hampir tidak memiliki kesempatan untuk melakukan aktivitas sesuai dengan minat keinginannya. ${ }^{29}$

Sedangkan

Ibu

Syu'layya Farida menegaskan bahwa, ada beberapa cara yang memang perlu untuk dilakukan dalam meningkatkan kecerdasan spiritual peserta didik di SMA Negeri 2 Situbondo, diantaranya adalah membuka dan menutup pelajaran dengan do'a dan menampilkan video-video yang mengandung hikamah. Tujuannya adalah mendorong peserta didik untuk selalu beriman dan bertakwa kepada Allah SWT. Dan mendorong peserta didik untuk selalu bermuhasabah (instropeksi diri). Hal ini sesuai dengan hadits Nabi Muhammad SAW.

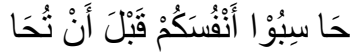
سَبْوُ ا.

Artinya: " periksalah dirimu sebelum kamu diperiksa”. ${ }^{30}$

${ }^{29}$ Rusman, 2012. Model-Model Pembelajaran membangun profesionalisme guru. Jakarta: PT Rajagrafindo Persada. Cet. Ke-5. hal.381

${ }^{30}$ Al-ghazali, 2007. Ringkasan Ihya'ulumuddin. Jakarta: Pustaka Amini. Cet. Ke-2. hal. 437
Selain itu juga menurut Ibu Syu'layya Farida, dalam menerapkan strategi perlu melihat pribadi dan karakteristik serta kemapuan individu peserta didik. Hal ini sesuai dengan pendapat Ngalimun bahwa, salah satu komponen strategi adalah peserta didik sebagai raw input artinya strategi pembelajaran digunakan dalam rangka membelajarkan peserta didik. untuk itu dalam pembelajaran seorang guru harus memperhatiakan siapa yang dihadapi. ${ }^{31}$

Sedangkan menurut Amaliyah Rahmah, tugas dan tanggung jawab seorang guru adalah memberikan nasehat dan berusaha membuat peserta didik untuk selalu belajar. Dalam hal ini maka guru harus memberikan nasehat yang baik dan mampu membuat peserta didik untuk proaktif di dalam pembelajaran.

Berdasarkan apa yang disampaikan Amaliyah Rahmah di atas tentang strategi guru PAI dalam meningkatkan kecerdasan spiritual peserta didik di SMA Negeri 2 Situbondo, lebih menempatkan guru PAI di samping sebagai mu'allim, murobbi, penasehat sekaligus sebagai pembimbing. Hal ini sesuai dengan apa yang diungkapkan oleh Hasan Basri bahwa, guru adalah adalah figur manusia yang diharapkan kehadiran dan perannya dalam pendidikan,

${ }^{31}$ Ngalimun, 2013. Strategi dan Model Pembelajaran. Yokyakarta: Aswaja Pressindo. Cet. Ke-2. hal. 15 
sebagai sumber yang menempati posisi dan memegang peranan penting dalam pendidikan. Ketika semua orang mempersoalkan masalah dunia pendidikan, figur guru mesti terlibat dalam agenda pembicaraan, terutama menyangkut masalah persoalan pendidikan formal di sekolah. $^{32}$

Guru adalah bapak rohani bagi anak didiknya. Hal ini berarti bahwa guru sebagai arsitek bagi anak didiknya. Kebaikan rohani anak didik bergantung pada pembinaan dan bimbingan guru. Di sini, tugas dan tanggung jawab guru adalah meluruskan tingkah laku dan perbuatan anak didik yang kurang baik, yang dibawanya dari keluarga dan masyarakat. ${ }^{33}$ Di samping itu, dalam penerapan strategi ini guru juga berposisi sebagai penasehat. Sebagaimana yang ditegaskan oleh Imam Wahyudi bahwa guru sebagai penasehat berarti guru berperan aktif dalam hal memberikan arahan bimbingan dan konseling terhadap peserta didik yang menghadapi permasalahan serta membantu menyelesaikannya. Karena guru sebagai orang tua di sekolah. Dalam melaksanakan perannya sebagai penasehat, maka guru harus mendekati peserta didiknya dengan

${ }^{32}$ Hasan Basri, 2009. Filsafat pendidikan Islam. Bandung: Pustaka Setia. Cet. Ke-1. 57

Islam. hal. 60 pendekatan psikologis. ${ }^{34}$ Jika dalam penerapan suatu strategi guru sebagai penasehat berarti strategi yang diterapkan mengarah pada strategi ekspositori (teacher center) adalah bentuk pembelajaran yang lebih menekankan pada bertutur atau bercerita secara verbal. Guru mempunyai peran paling utama untuk bertutur di hadapan siswa. Para siswa bertugas untuk menyimak dengan baik materi yang disampaikan oleh guru. ${ }^{35}$

Dalam hal ini juga guru PAI sebagai mu'allim sekaligus murobbi memiliki tugas yang sangat penting, yaitu memberi nasehat kepada anak didik nya seabagaimana yang diungkapkan oleh oleh KHR. As'ad Syamsul Arifin pendiri pengasuh ke-II pondok pesantren Salfiyah Syafi'iyah bahwa murabbi tidak hanya menularkan ilmu kepada santrinya (peserta didiknya) tetapi lebih dari itu ia harus mampu memperbaiki sikap dan menanamkan nilai dalam diri santrinya (peserta didiknya). ${ }^{36}$

2. Faktor-faktor yang Mendukung dan menghambat Penerapan Strategi Guru PAI dalam Meningkatkan Kecerdasan Spiritual Peserta Didik Di SMA Negeri 2 Situbondo

${ }^{34}$ Imam wahyudi , 2012. Mengejar profesionalisme guru. Jakarta: Prestasi Pustakaraya. Cet. Ke-1. Hal. 49-50

${ }^{35}$ Rudi Hartono, 2013. Ragam Model Mengajar yang Mudah Diterima Murid. Jogjakarta: DIVA Press, Cet. Ke-1 hal. 45

${ }^{36}$ Edisi : 3/10 Maret 2014. Majalah New Mafahim. surabaya: Hai'ah AshShofyah Al-malikiyah, Cet. Ke- 3, h. 34 
Setiap kegiatan belajar mengajar yang dilakukan oleh guru sudah barang tentu ada faktor yang mendukung dan menghambat.

a. Faktor yang mendukung

Menurut Bapak Nur Budi, faktor yang mendukung adalah apresiasi dan dukungan aparat sekolah, guru, dan partisipasi akatif dari sebagian peserta didik SMA Negeri 2 Situbondo terhadap suksesnya langkah-langkah guru PAI dalam meningkatkan kecerdasan spiritual peserta didik. Hal ini sesuai dengan apa yang diungkapkan Ngalimun bahwa salah satu komponen strategi adalah situasi atau lingkungan. Lingkungan sangat mempengruhi guru dalam menentukan strategi pembelajaran. lingkungan yang dimaksud adalah situasi dan keadaan fisik (misalnaya iklim, madrasah, letak madrasah, dan lain sebagainya), dan hubungan antar insani, misalnya dengan teman, dan peserta didik dengan orang lain. ${ }^{37}$

Menurut Ibu Syu'layya Farida, menumbuhkan minat dan pandangan pesrta didik merupakan salah satu upaya atau cara yang harus dilakukan oleh seorang guru untuk membentuk manusia yang cerdas secara jasmani

${ }^{37}$ Ngalimun, Strategi dan Model

Pembelajaran. hal. 15 dan rohani. Untuk menumbuhkan minat dan pandangan peserta didik juga dibutuhkan dukungan dari pihak-pihak yang terkait termasuk lingkungan. Hal ini sesuai dengan pernyataan Imam Wahyudi bahwa, guru sebagai pembangkit pandangan adalah guru memiliki peranan dalam merubah dan membangkitkan pandangan yang salah di masa lalu, dan memperbaiki pandangan yang ada di mata anak didiknya dan membimbing mereka dalam menatap kebenaran. ${ }^{38}$ Selain itu juga dalam penerapan strategi maka guru sekurangkurangnya memperhatikan kondisi atau lingkungan. Karena menurut Ngalimun di atas bahwa situasi atau lingkungan memiliki pengaruh yang sangat besar terhadap penerapan suatu strategi, lingkungan itu bisa berupa teman, dan orangorang yang ada di sekitar kita

Sedangkan menurut
Amaliah Rahmah,
keingintahuan peserta didik
terhadap pendidikan agama
meruapakan salah satu hal
yang sangat penting untuk
mencapai tujuan
pendidikan. Karena peserta
didik merupakan objek dari
pada pendidikan. Dalam
kegiatan pengajaran siswa

${ }^{38}$ Imam wahyudi , 2012. Mengejar profesionalisme guru. Jakarta: Prestasi Pustakaraya. Cet. Ke-1. Hal. 49 
atau peserta didik selalu menjadi sorotan yang utama. Oleh karena itu maka, guru harus memperhitungkan siapa yang dihadapinya, baik tingkat intelektual, latar belakang pendidikan, tingkat usia maupun lingkungan sosial budayanya. ${ }^{39}$ Maka dalam hal ini minat, kesadaran, dan keingintahuan peserta didik harus dibangun dengan baik.

Menurut Bapak
Mudhaffar faktor yang
mendukung $r$ adalah
kesadaran dari sebagian
peserta didik untuk
mengaplikasikan nilai-niali
pendidikan. Hal ini terbukti
pada saat jam-jam istirahat
menyempatkan untuk
melakukan sholat dhoha.
Kesadaran yang dimiliki
oleh sebagian peserta didik
menjadi bukti bahwa dia
benar-benar memiliki
kecerdasan spiritual. Untuk
itu maka guru sekurang-
kurangnya berusaha untuk
mengembangkan
kecerdasan spiritual yang
mereka miliki. Menurut
Agus Nggermanto,
langkah-langkah
mengembangkan
kecerdasan lain: menyadari
anatara lain:
situasi, ingin berubah,
mengenali
menyingkirkan

${ }^{39}$ Skripsi. Raf'i, 2013. Starategi Guru dalam Peningkatkan Motivasi Belajar Siswa di Ma'had Aly Marhalah Ula Situbondo. hal. 21 hambatan,disiplin, makna terus menerus hormati mereka $^{40}$

b. Faktor-faktor yang menghambat Menurut Ibu Syu'layya farida, faktor yang menghambat adalah kurangnya dukungan dari wali murid, hal ini terbukti ketika ada salah satu siswa yang ingin berbuat baik malah oleh orang tuanya diabaikan dan bahakan digojlok. Hal ini menunjukkan bahawa lingkungan sebagai salah satu komponen dan faktor yang mempengaruhi strategi tidak hanya berpotensi sebagai faktor yang mendukung, tapi juga berpotensi sebagai faktor yang menghambat, maka dalam hal ini lingkungan telah berpotensi sebagai faktor yang menghambat. Menurut Ngalimun situasi atau lingkungan sangat mempengruhi guru dalam menentukan strategi pembelajaran. lingkungan yang dimaksud adalah situasi dan keadaan fisik (misalnaya iklim, madrasah, letak madrasah, dan lain sebagainya), dan hubungan antar insani, misalnya dengan teman, dan peserta didik dengan orang lain. ${ }^{41}$

$$
\text { Menurut Amaliah }
$$
Rahmah, faktor yang

${ }^{40}$ Agus Nggermanto, 2003. Quantum Quontient. Yayasan Nuansa Cendikia: Cet. Ke-5. Hal hal 144-147

${ }^{41}$ Ngalimun, Strategi dan Model

Pembelajaran. hal. 15 
menghambat adalah pribadi peserta didik itu sendiri, artinya tidak semua peserta didik memiliki kesadaran untuk belajar agama, sehingga kurangnya kesadaran dari sebagian peserta didik untuk belajar agama menjadi salah satu faktor yang menghambat strategi guru PAI di SMA Negeri 2 Situbondo.

Menurut Nagalimun Peserta didik merupakan komponen yang melakukan kegiatan belajar untuk mengembangkan potensi kemampuan menjadi nyata untuk mencapai tujuan belajar. Komponen ini dapat dimodifikasi oleh guru. ${ }^{42}$ Dengan demikian tidak menutup kemungkinan bahwa siswa sebagai objek pendidikan bisa berpotensi sebagai faktor yang mendukung tapi juga bisa berpotensi sebagai faktor yanfg menghambat strategi yang diterapkan guru.

Sedangkan menurut Bapak Nur Budi faktor yang menghambat adalah waktu dan pengaruh teman. Hal ini terbukti ketika kebanyakan peserta didik memiliki semangat untuk aktif di dalam kegiatan-kegiatan keagamaan, namun karena pengaruh teman juga terkadang karena banyak jadwal-jadwal kegiatan yang berbenturan. Sehingga peserta didik tidak fokus

${ }^{42}$ Ngalimun, Strategi dan Model

Pembelajaran. hal. 13 mana yang lebih didahulukan.

Sebagaimana yang maklum bahwa salah satu ciri-ciri strategi itu adalah wawasan waktu, meliputi cakrawala waktu yang jauh ke depan, yaitu waktu yang diperlukan untuk melaksanakan kegiatan tersebut dan waktu yang diperlukan untuk mengamati dampaknya. ${ }^{43}$ Dalam hal ini dapat dipahami juga bahwa waktu bisa juga menjadi faktor penghambat strategi guru, manakala waktu yang dibutuhkan dalam menerapkan suatu strategi itu terganggu.

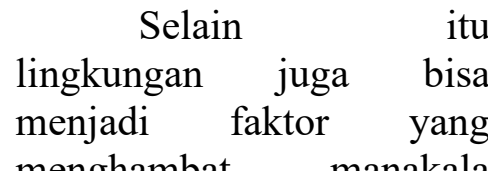
menghambat manakala lingkungan tersebut dapat membawa ke arah yang kurang baik. Hal ini merupakan interpretasi dari perkataan Ngalimun bahawa situasi atau lingkungan sangat mempengruhi guru dalam menentukan strategi pembelajaran. lingkungan yang dimaksud adalah situasi dan keadaan fisik (misalnaya iklim, madrasah, letak madrasah, dan lain sebagainya), dan hubungan antar insani, misalnya dengan teman, dan peserta didik dengan orang lain. ${ }^{44}$

\footnotetext{
${ }^{43}$ Hamdani, Srtategi Belajar

Mengajar. hal. 18

${ }^{44}$ Ngalimun, Strategi dan Model

Pembelajaran. hal. 15
} 
Sedangkan menurut bapak Mudhaffar, faktor yang menghambat adalah kondisi pengaruh lingkungan dan pergaulan peserta didik di rumah, hal ini terbukti ketika peserta didik itu ditanya apakah dirumahnya melaksanakan sholat, ternyata sebagian dari peserta didik ada yang menjawab kadang-kadang. Hal ini menunjukkan bahwa lingkungan memiliki pengaruh yang dapat menjadi penghambat strategi guru. Artinya tidak semua lingkungan itu menjadi faktor yang mendukung tapi juga menjadi faktor penghambat. Menurut Ngalimun situasi atau lingkungan sangat mempengruhi guru dalam menentukan strategi pembelajaran. lingkungan yang dimaksud adalah situasi dan keadaan fisik (misalnaya iklim, madrasah, letak madrasah, dan lain sebagainya), dan hubungan antar insani, misalnya dengan teman, dan peserta didik dengan orang lain. ${ }^{45}$

3. Solusi Mengatasi Hambatan Penerapan Strategi Guru PAI dalam Meningkatkan Kecerdasan Spiritual Peserta Didik di SMA Negeri 2 Situbondo:

$\begin{array}{lrr} & \text { Menurut } & \text { Ibu } \\ \text { Syu'layya } & \text { Farida, untuk } \\ \text { mengatasi } & \text { hambatan } \\ \text { kurangnya } & \text { dukungan dari } \\ \text { sebagian orang tua adalah }\end{array}$

${ }^{45} \mathrm{Ngalimun}$, Strategi dan Model

Pembelajaran. hal. 15 memberikan pengertian dan nasehat. Dalam hal ini posisi guru sebagai pendidik sebagaimana yang diungkapkan oleh Wiji Suwarno bahwa, pendidik adalah orang yang dengan sengaja memengaruhi orang lain untuk mencapai tingkat kemanusiaan yang lebih tinggi. Dengan kata lain, pendidik adalah orang yang lebih dewasa yang mampu membawa peserta didik kearah kedewasaan. Dalam penerapan suatu strategi yang menempatkan guru sebagai pendidik, penasehat, dan pembimbing berati strategi yang ditrapkan lebih mengarah kepada strategi ekspositori (Teacher Centered). Di smaping itu juga guru harus bertindak sebagai penasehat. Menurut Imam Wahyudi guru sebagai penasehat berarti guru berperan aktif dalam hal memberikan arahan bimbingan dan konseling terhadap peserta didik yang menghadapi permasalahan serta membantu menyelesaikannya. Karena guru sebagai orang tua di sekolah. Dalam melaksanakan perannya sebagai penasehat, maka guru harus mendekati peserta didiknya dengan pendekatan psikologis. ${ }^{46}$

Menurut Bapak Moh. Nur Budi solusi tentang waktu dan pengaruh teman adalah memberikan semacam motivasi-motivasi sebelum pembelajaran dimulai, kemudian dalam kegiatan

\footnotetext{
${ }^{46}$ Imam wahyudi, Mengejar

profesionalisme gur. Hal. 50
} 
keagamaan berusaha menghadirkan penceramahpenceramah yang memang berkualitas dari segi pemahaman berpikir dan pemahaman rohani. Dalam hal ini guru sebagai motivator artinya guru sekurangkurangnya mampu mendorong peserta didik untuk aktif, inovatif, kreatif, dan senang terhadap materi pelajaran yang disajikan.

Bapak $\begin{array}{rr}\text { Sedangkan menurut } \\ \text { Mudhaffar, solusi }\end{array}$ tentang kondisi pengaruh lingkungan dan pergaulan anak dirumah adalah memberikan semacam lembar kontrol kepada peserta didik dalam satu bulan satu kali dengan menanyakan aktivitas dirumahnya masing-masing. Dalam memberikan kontrol maka sekurang-kurangnya guru harus menjadi penasehat.

\section{Kesimpulan}

a. Bahwa penerapan strategi guru PAI dalam meningkatkan kecerdasan spiritual peserta didik di SMA Negeri 2 Situbondo adalah memberi tambahan kegiatan keagamaan, membiasakan peserta didik mengikuti kegiatan-kegiatan keagamaan, memulai dan mengakhiri pelajaran dengan do'a, menampilkan videovideo yang mengandung hikmah, melihat individu dan kemampuan peserta didik, memberi nasehat dan tanya jawab, berdzikir dan mendo'akan peserta didik.

b. Faktor-faktor yang mendukung dan menghambat penerapan strategi guru PAI dalam meningkatkan kecerdasan spiritual peserta didik di SMA Negeri 2 Situbondo.

1. Faktor-faktor yang mendukung penerapan strategi guru PAI dalam meningkatkan kecerdasan spiritual peserta didik di SMA Negeri 2 Situbondo, adalah: minat dan kesadaran sebagian peserta didik untuk belajar agama, dukungan sebagian wali murid, keingintahuan peserta didik, apresiasi dan dukungan kepala sekolah, guru, dan partisipasi aktif sebagian peserta didik terhadap langkah-langkah guru PAI, dan kesadaran dari sebagian peserta didik untuk melaksanakan nilainilai pendidikan agama.

2. Faktor-faktor yang menghambat penerapan strategi guru PAI dalam meningkatkan kecerdasan spiritual peserta didik di SMA Negeri 2 Situbondo, adalah: Kuarangnya dukungan dari sebagian wali murid, individu peserta didik, waktu dan pengaruh teman, serta kondisi pengaruh lingkungan dan pergaulan peserta didik di rumah.

c. Solusi mengatasi penghambat penerapan strategi guru PAI dalam meningkatkan kecerdasan spiritual peserta didik di SMA Negeri 2 Situbondo adalah: memberi pengertian kepada wali murid, memberi semacam motivasimotivasi kepada peserta didik, 
dan memberikan semacam lembar kontrol kepada peserta didik yang berisi pertanyaan tentang aktivitas dirumahnya setiap satu bulan satu kali.

\section{Daftar Pustaka}

Wiji Suwarno, 2006. Dasar-Dasar

Ilmu Pendidikan. yogyakarta: Penerbit Arruzz Media Cet Ke 1.hal 21

Hasan Basri, 2009. Filsafat

pendidikan Islam. Bandung: Pustaka Setia. Cet. Ke-1. hal. 53

Zuhairi Misrawi, Revitalisasi islam" Supriyadi, A., Patmawati, F., \& Waziroh, I. (2023). STRATEGI PEMBELAJARAN EKSPOSITORI UNTUK ANAK BERKEBUTUHAN KHUSUS JENIS TUNARUNGU PADA MATA PELAJARAN PENDIDIKAN AGAMA ISLAM. Edupedia: Jurnal Studi Pendidikan dan Pedagogi Islam, 7(2), 177-188.

Hosaini, H. (2020). Pembelajaran dalam era "new normal" di pondok pesantren Nurul Qarnain Jember tahun 2020. LISAN AL-HAL: Jurnal Pengembangan Pemikiran dan Kebudayaan, 14(2), 361-380.

Samsudi, W., \& Hosaini, H. (2020). Kebijakan Sekolah dalam Mengaplikasikan

Pembelajaran Berbasis Digital di Era Industri 4.0. Edukais: Jurnal Pemikiran Keislaman, 4(2), 120-125.

Mahtum, R., \& Zikra, A. (2022, November). Realizing Harmony between Religious People through Strengthening Moderation Values in Strengthening Community Resilience After the Covid 19 Pandemic. In The 4th International Conference on University Community Engagement (ICON-UCE 2022) (Vol. 4, pp. 293-299).
Hosaini, H., \& Samsudi, W. (2020). Menakar Moderatisme antar Umat Beragama di Desa Wisata Kebangsaan. Edukais: Jurnal Pemikiran Keislaman, 4(1), 1-10.

Hosaini, H., \& Kurniawan, S. (2019). Manajemen Pesantren dalam Pembinaan Umat. Edukais: Jurnal Pemikiran Keislaman, 3(2), 82-98.

Muis, A., Eriyanto, E., \& Readi, A. (2022). Role of the Islamic Education teacher in the Moral Improvement of Learners. AtTarbiyat: Jurnal Pendidikan Islam, 5(3).

Halim, A., Hosaini, H., Zukin, A., \& Mahtum, R. (2022). PARADIGMA ISLAM MODERAT DI INDONESIA DALAM MEMBENTUK PERDAMAIAN

DUNIA. JISMA: Jurnal Ilmu Sosial, Manajemen, dan Akuntansi, 1(4), 705-708.

Zukin, A., \& Firdaus, M. (2022). Development Of Islamic Religious Education Books With Contextual Teaching And Learning. At-Tarbiyat: Jurnal Pendidikan Islam, 5(1).

Hosaini, H., Zikra, A., \& Muslimin, M. (2022). EFFORTS TO IMPROVE TEACHER'S PROFESSIONALISM IN THE TEACHING LEARNING PROCESS. $A l$ Risalah: Jurnal Studi Agama dan Pemikiran Islam, 13(2), 265-294.

Salikin, H., Alfani, F. R., \& Sayfullah, H. (2021). Traditional Madurese Engagement Amids the Social Change of the Kangean Society. RETORIKA: Jurnal Ilmu Bahasa, 7(1), 3242. 
Hosaini, H., \& Fikro, M. I. (2021). PANCASILA SEBAGAI WUJUD ISLAM RAHMATAN LI ALALAMIIN. Moderation|

Journal of Islamic Studies Review, 1(1), 91-98.

Hosaini, H. (2020). Ngaji Sosmed Tangkal Pemahaman Radikal melalui Pendampingan Komunitas Lansia dengan sajian Program Ngabari di Desa Sukorejo Sukowono Jember. As-Sidanah: Jurnal Pengabdian Masyarakat, 2(1), 159-190.

Agustin, Y. D., Hosaini, H., \& Agustin, L. (2021). ANALYSIS OF THE IMPACT OF EARLY MARRIAGE ON ADOLESCENT REPRODUCTIVE HEALTH BASED ON HEALTH PERSPECTIVES AND ISLAMIC RELIGION. UNEJ e-Proceeding, 103-107.

Hosaini, H., \& Kamiluddin, M. (2021). Efektivitas Model Pembelajaran Means-Ends Analysis (MEA) dalam meningkatkan Keterampilan Komunikasi Interpersonal dan Pemecahan Masalah pada mata pelajaran Fikih. Edukais: Jurnal Pemikiran Keislaman, 5(1), 43-53.

Hosaini, $\mathrm{H}$. (2020). PEMBELAJARAN DALAM ERA "NEW NORMAL" DI PONDOK PESANTREN NURUL QARNAIN JEMBER TAHUN 2020. LISAN ALHAL: Jurnal Pengembangan Pemikiran dan Kebudayaan, 14(2), 361-380. Hosaini, H. (2019). Behauvioristik Basid Learning Dalam
Bingkai Pendidikan Islam Perspektif Al-Ghazali:(Pembelajaran Berbasis Prilaku Dalam Pandangan Pendidikan Islam). Edukais: Jurnal Pemikiran Keislaman, 3(1), 23-45.

Muslimin, M., \& Hosaini, H. (2019). KONSEP PENDIDIKAN ANAK MENURUT ALQUR'AN DAN HADITS. Edupedia: Jurnal Studi Pendidikan dan Pedagogi Islam, 4(1), 67-75.

Hosaini, H., \& Erfandi, E. (2017). Studi Komparasi Konsep Pendidikan Karakter Menurut KH. Hasyim Asy'ari dan Ki Hadjar Dewantara. Edukais: Jurnal Pemikiran Keislaman, 1(1), 136.

Agustin, L., Rahayu, L. P., Hosaini, H., Agustin, Y. D., \& Utami, C. B. (2022). Penyuluhan Kesehatan Reproduksi pada Remaja dalam Perspektif Kesehatan dan Hukum. DEDICATION: Jurnal Pengabdian Masyarakat, 2(2), 16-21. 